\title{
Сейтумеров А.И.О.
}

\section{Особенности мотивации спортсменов командных и индивидуальных видов спорта}

ГБОУВО РК «Крымский инженерно-педагогический университет имени Февзи

doi: $10.18411 / \mathrm{j}-06-2020-463$

(Россия, Симферополь)

idsp: ljournal-06-2020-463

\section{Аннотация}

В статье представлены особенности повышения спортивной мотивации перед лицом профессиональных спортсменамов; теоретически было выдвинуто предположение о том, что спортивная мотивация представителей индивидуальных и командных видов спорта содержит в себе ряд существенных различий; рассмотреть современные и классические теории по проблематике психологии спорта, а также по проблемам спортивной мотивации, личностным особенностям, что помогают добиваться успеха в спортивной деятельности.

Ключевые слова: спортивная деятельность; повышение спортивной мотивации; профессиональные спортсмены; командный спорт; индивидуальный спорт.

\section{Abstract}

The article presents the features of increasing sports motivation in front of professional athletes; theoretically, it was suggested that the sports motivation of representatives of team and individual sports contains a number of significant differences; to consider classical and modern theories on the problems of the psychology of sports, as well as on the problems of sports motivation, personal characteristics that help to achieve success in sports activities.

Keywords: sports activities; increase sports motivation; professional athletes; team sport; individual sport.

Введение. Выделяя основные особенности данных исследований, мы говорим о их междисциплинарном и межотраслевом характере, это обстоятельство предопределяется устойчивым интересом исследователей к специфике спортивной деятельности, поскольку именно в ней человек постоянно преодолевает субъективное чувство усталости, утомление, психологический дискомфорт, однако при этом, стремиться к высоким достижениям, активно тратит свою энергию и силы.

Перед профессиональными спортсменами всегда довольно остро стоит проблема повышения спортивной мотивации. Множество авторов отмечает, что первоначально спорт развился как тренировочная деятельность воинов и охотников. Из этого можно сделать логическое заключение: спортивная мотивация сформировалась из стремления удовлетворять основные потребности человека - потребности в безопасности (противостояние стихиям, или защита собственного племени побуждала человека быть сильным и выносливым), пропитании (необходимость добывать пищу требовала силы, физической формы и выносливости), а также потребности в выигрыше в социальном соревновании (стремление завоевать более высокое положение в социальной иерархии статусов)

Актуальность данной темы в том, что эволюция спорта как вида деятельности радикально изменила и его характер (спорт стал профессиональной деятельностью), из этого вытекает изменение в особенностях спортивной мотивации, и как следствие, изменение ведущих мотивов спортсменов. Многие отечественные ученые А.Я. Дука, Е.П. Ильин, В.Н. Непопалов, Р.А. Пилоян, А.В. Родионов, В.Ф. Сопов, Г.П. Фураев, Н.А. Худадов работали над изучением проблемы спортивной мотивации. Их исследования в основном затрагивают вопросы материальных потребностей в 
структуре спортивной мотивации, влияние социально-бытовых потребностей на спортивную деятельность, особенности мотивации спортсменов с различной направленностью личности и т. д.

Целью исследования является выявление особенностей спортивной мотивации у представителей командных и индивидуальных видов спорта.

Изложение основного материала. В ходе исследования особенностей мотивации спортсменов были установлены следующие задачи:

1. Рассмотреть классические и современные теории по проблематике психологии спорта, а также по проблемам спортивной мотивации, личностным особенностям, что помогают добиваться успеха в спортивной деятельности.

2. Выделить методический инструментарий, который позволит изучить особенности спортивной мотивации в социально-психологическом контексте и провести сравнительный анализ ее структуры у представителей командных и индивидуальных видов спорта.

3. Установить характер взаимосвязей между различными мотивационными составляющими, такими, как направленность в спортивной деятельности, зависть, а также рассмотреть возрастные особенности и половую специфику мотивации в спорте высших достижений.

4. На основании проведенного исследования сформулировать итоговые выводы.

Изнуряющие физические нагрузки приводят к наибольшей активности центральной нервной системы. Реагируя на это в организме человека возникают субъективные ощущения усталости, истощения, психологического дискомфорта, что организм воспринимает, как неприятные переживания. Таких переживаний в обычной жизни человек старается избегать. То есть, в нормальном состоянии организм человека реагирует на большие физические нагрузки, в соответствии с их тяжестью, отрицательно.

Мотивация - это главная переменная овладения спортивными навыками и умением их продемонстрировать. В первую очередь, мотивация - это стремление к успеху, к достижению высоких результатов в выбранной деятельности.

По сути, мотивация - это широкое понятие, объединяющее в себе сложный процесс управления направлением и интенсивностью усилий. Действительное представление о мотивации может быть тогда, когда будут осознаны не мотивационные воздействия на спортивную деятельность и поведение, а также если научиться определять возможность быстрого изменения мотивационных факторов.

Человека побуждает к занятиям спортом чувство удовлетворения, которое вызвано этим видом спорта.

Рассмотрим главные мотивы спортивной деятельности:

1. спортсмен чувствует некоторое удовлетворение от проявления мышечной активности;

2. спортсмен ощущает эстетическое наслаждение красотой, точностью, ловкостью своих движений;

3. спортсмен стремиться проявить смелость и решительность при выполнении трудных и опасных упражнений;

4. спортсмен, участвуя в соревнованиях, ощущает удовлетворение;

5. спортсмен старается добиться наивысших результатов, доказать свое спортивное мастерство и т.д.

Косвенные мотивы спортивной деятельности:

1. стремление укрепить здоровье, ощутить бодрость и энергию; 
2. стремление подготовить себя к практической деятельности посредством спортивных занятий;

3. осознание общественной важности спортивной деятельности [17].

На сегодняшний день рассматривают три теории, побуждающие человека к действию: потребности достижения; атрибуции; достижения цели.

В спортивной психологии, как правило, выделяют два параметра мотивации: мотивации достижения успеха и мотивации избегания неудач. Для осуществления первого аспекта деятельность и состояние спортсмена должны отвечать следующим требованиям:

- спортивная деятельность должна приносить определенный результат, оцениваемый качественно и количественно;

- для оценки результата должны быть определенные критерии, определяющие, в частности, необходимый нормативный уровень;

- деятельность должна быть желанной, а результат получен самостоятельным путем.

Этот аспект встречается у спортсменов чаще, чем мотивация избегания.

В последние годы многие психологи исследовали мотивации высококвалифицированных спортсменов (направленность на успех и на избегание неудач). Результаты их исследований дают нам возможность утверждать, что у успешных спортсменов уровень мотивации, направленной на достижение успеха, всегда примерно на 50\% выше направленности на избегание неудачи. Если же это соотношение ниже, то можно предположить, что спортсмен хочет завершить карьеру, или ему предложили перейти в другую команду, клуб; быть может он переосмыслил свои ценности не в пользу спорта, а может появились другие причины не наносить вред своему здоровью в данный период времени.

Большинство исследований личностных особенностей спортсменов и тех, кто не занимается спортом, говорят о довольно больших отличиях в уровнях выраженности целого ряда личностных качеств. Проводимые исследования больших групп спортсменов высокой квалификации дало возможность увидеть, что наиболее характерными особенностями их личности являются: высокое эмоциональное равновесие, уверенность в себе, суверенность, самостоятельность, склонность к риску, самоконтроль, общительность.

Спортсмену для достижения успеха необходимо самостоятельно выстраивать программу деятельности, выдвигать реалистичные, детализированные цели, адекватно оценивать результаты и самостоятельно их корректировать.

Выводы: Мотивация спортивной деятельности определяется психофизиологией спортсмена, его волей, а также уровнем притязаний. Каждый из этих компонентов играет большую роль и помогает в достижении успеха деятельности.

Эффективное равновесие целей и средств их достижения предполагает оценку успеха деятельности как по конечному результату, так и по процессу. В этом случае моральное и материальное удовлетворение формируется не только в процессе достижения поставленной цели, но и при использовании честных методов их достижения.

Спортивная деятельность с полным основанием может рассматриваться как совместная деятельность, включающая в себя весь спектр социально-психологических феноменов общения, взаимовлияний, лидерства, методов руководства. Работа тренера поддерживает положительный эмоциональный контакт и предупреждает напряжение и конфликты в межличностном общении со спортсменом. Неприятие спортсменами тренера как личности и как специалиста может привести к снижению спортивной результативности. 
Успехи в спортивной деятельности зависят от способностей, навыков, знаний, от планирования деятельности и оценки ее результатов, а также от особенностей мотивационных процессов.

$$
* * *
$$

1. Алексеев А.В. Преодолей себя! Психическая подготовка в спорте. - Ростов-на-Дону: Феникс, 2006. -354 c.

2. Андреева Г.М. Социальная психология: Учебник для высшего учебного заведения. — М.: Аспект Пресс, 2001. - 384 с.

3. Андреева Г.М. Психология социального познания: Учеб. пособие для студентов вузов / Г. М. Андреева. - 3 е изд., перераб. и доп. - М.:Аспект Пресс, $2009-303$ с.

4. Анцупов А.Я., Шипилов А.И. Конфликтология: Учебник для вузов. - М.: ЮНИТИ, 2000 - 551 с.

5. Волков И.П. Спортивная психология в трудах отечественных специалистов: хрестоматия / сост. и общая редакция И. П. Волкова. - СПб.: Питер, 2002. - 384 с

6. Блудов Ю.М., Плахтиенко В.А. Личность в спорте: Очерки исслед. психологии спортсмена / Ю. М. Блудов, В. А. Плахтиенко. - М.: Сов. Россия, 1987. - 154 с.

7. Волков И.П. Спортивная психология в трудах зарубежных специалистов: хрестоматия. - М.: Советский спорт, 2005. - 286 с.

\section{Сильченко С.С. \\ Смысложизненные ориентации педагогических работников с различным уровнем профессионального выгорания}

ГБОУВО РК«Крымский инженерно-педагогический университет» (Россия, Симферополь)

doi: $10.18411 / \mathrm{j}-06-2020-464$

idsp: ljournal-06-2020-464

\section{Аннотация}

Статья посвящена исследованию особенностей ценностно-смысловой сферы педагогов с различным уровнем профессионального выгорания. Она раскрывает особенности самоактуализации, ценностей, смысложизненных ориентаций и аспектов самоотношения педагогов с разными уровнями выраженности аспектов, фаз и симптомов выгорания.

Ключевые слова: смысложизненные ориентации, профессиональная мотивация, профессиональная адаптация, методика смысло-жизненных ориентаций Д.А.Леонтьева, методика диагностики ценностных ориентаций М.Рокича.

\section{Abstract}

The article is devoted to the study of the features of the value-semantic sphere of teachers with different levels of professional burnout. It reveals the features of selfactualization, values, life orientations and aspects of self-attitude of teachers with different levels of expression of aspects, phases and symptoms of burnout.

Keyword: meaning-life orientations, professional motivation, professional adaptation, method of meaning-life orientations of D. A. Leontiev, method of diagnostics of value orientations of M. Rokich.

Постановка проблемы. Интенсификация профессиональной деятельности педагогов, информационные, коммуникативные, эмоциональные перегрузки, истощение адаптивных ресурсов актуализируют проблему сохранения их физического и психического здоровья, обеспечения устойчивости к профессионально обусловленных заболеваний и расстройств, в частности профессионального выгорания. 